\title{
The influence of debt policies, profitability and corporate social disclosures responsibility to tax agresivity
}

\author{
Afiyatul Khafifah \\ Universitas Islam Negeri Walisongo Semarang, Indonesia \\ email: afi.khafifah14@gmail.com
}

\begin{abstract}
Purpose - The research objective is to determine the effect of debt policy, profitability, and Corporate Social Responsibility (CSR) on tax aggressiveness in mining sector companies listed in the Indonesian Sharia Stock Index for the period 2014-2019.
\end{abstract}

Method - The population of this study was 35 mining companies listed on the Indonesian Sharia Stock Index for 2014-2019. The sample selection in this study used purposive sampling method and 6 companies were selected. The data analysis used multiple linear regression analysis. Three tests were conducted; determinant coefficient test, simultaneous significant test, and partial regression test (T-Test).

Result - The results show that debt policy (DAR) has a significant negative effect on tax aggressiveness, Profitability (ROA) has a significant negative effect on tax aggressiveness, and disclosure of Corporate Social Responsibility (CSR) has a significant negative effect on tax aggressiveness.

Implication - Mining companies registered in the ISSI for the 2014-2019 period have proven that their tax aggressiveness is low, which means they are compliant with tax payments. However, on the other hand, the company must maintain and improve compliance in paying taxes.

Originality - This study is the first study using a sharia mining company registered with the ISSI related to tax aggressiveness.

Keywords: debt policy; profitability; csr; tax aggressiveness

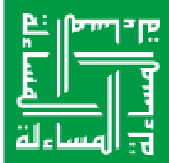


Afiyatul Khafifah

\section{Introduction}

Tax is an effort that can be done to explore the source of funds used in financing development, because in Indonesia, tax is a source of state revenue JIAFR | 114 that is placed in the top position. About $80 \%$ of the source of state revenue comes from taxes (Selviani and Supriyanto, 2019).

Tax revenue in Indonesia has fluctuated and has not yet reached the target set. In 2014 to 2015 it has decreased, while from 2015 to 2018 the percentage increased. However, the percentage in 2019 decreased to $7.6 \%$ from 2018. From 2014 to 2019, the least tax revenue realization occurred in 2015, namely 82\%, and in 2018 it was the largest tax revenue collection, namely $92 \%$.

On July 5, 2013, the Chairman of the Corruption Eradication Commission (KPK) Abraham Samad stated that $60 \%$ of mining companies in Indonesia did not pay taxes and royalties, thus causing the state losses of around Rp. 100 trillion to Rp. 120 trillion (Darussalam, 2020). The next phenomenon occurred in 2016, where according to the Natural Resources (SDA) Coordinator stated that the 2016 taxation data showed that mining companies on average were indicated to be acting tax aggressively. Data on about 11,000 mining permits show that there are 4000 companies experiencing problems, one of which is not being compliant in paying taxes (Gabrillin, 2018).

Table 1. Target and Realization of Tax Revenue Data in Indonesia 2014-2019 (in trillion Rupiah)

\begin{tabular}{crrc}
\hline Year & \multicolumn{1}{c}{$\begin{array}{c}\text { Tax Revenue } \\
\text { Target }\end{array}$} & $\begin{array}{c}\text { Actual Tax } \\
\text { Revenue }\end{array}$ & $\begin{array}{c}\text { Achievement } \\
\text { Level }\end{array}$ \\
\hline $\mathbf{2 0 1 4}$ & 1.246 .1 & $1,143,3$ & $91.6 \%$ \\
$\mathbf{2 0 1 5}$ & $1,294,3$ & $1,055,61$ & $82 \%$ \\
$\mathbf{2 0 1 6}$ & $1,539.17$ & 1.283 .6 & $83.4 \%$ \\
$\mathbf{2 0 1 7}$ & 1.283 & 1.147 & $89.4 \%$ \\
$\mathbf{2 0 1 8}$ & 1,424 & $1,315,9$ & $92 \%$ \\
$\mathbf{2 0 1 9}$ & $1,577,6$ & $1,332,1$ & $84.4 \%$ \\
\hline
\end{tabular}

Source: Ministry of Finance of the Republic of Indonesia 
So far, the tax revenue set in Indonesia has not met the target set by the government. The government has not been able to maximize the realization of tax revenue in accordance with its target. It raises a question, that is whether there are actions taken by taxpayers starting from avoiding tax payments in legal or illegal forms called tax aggressiveness, or the actual tax collection has not been implemented properly and optimally (Latifah, 2018).

Companies minimize tax costs by tax aggressiveness. Tax aggressiveness provides its own benefits for companies that do so, but on the other hand, these actions are detrimental to the state and can lead to negative assessments on the community, especially the community around the company and can affect the good name and reduce the company's reputation (Gunawan, 2017).

Several previous researchers conducted research on the explanation of the factors that cause the emergence of tax aggressiveness that occurs in companies, one of which is debt policy. The results of previous research stated that debt policy affects tax aggressiveness, where research from Irsan and Suryani (2018) and Jeane (2018) argued that debt policy has a significant positive effect on tax aggressiveness, the higher the company's debt policy, the higher the aggressive actionin terms of taxation (Atari, 2016).

Another factor, namely profitability, is a ratio that can determine how much the company's ability to earn a profit (Tarigan, 2016). A study conducted by Sarjito and Sari (2016) shows that profitability has a significant and negative effect on tax aggressiveness. It concluded that the higher the profit earned by the company, the higher the tax burden that must be borne, and the more honest the company is to pay its taxes than which has low profitability (Surya \& Noerlaela, 2018). But the results of this research contradict Risma's (2016) research which states that profitability has a positive but insignificant effect, meaning that if the company has high profits, the company's tax burden to be paid can be minimized, but high profits have little impact on the goal of minimizing the tax burden (Cahyani, 2016). 
The next factor of social and environmental responsibility in the company is known as Corporate Social Responsibility (CSR) activities. Research by Rakhma (2018) explains that CSR has a significant positive effect on tax aggressiveness, which shows that companies with CSR disclosure have a tendency to commit tax aggressiveness, and it can be said that CSR is used by companies to disguise tax aggressiveness.

This research uses objects from mining sector companies that are members of the Indonesian Sharia Stock Index (ISSI). The selection of these objects was aimed to find out whether companies registered in the ISSI are doing tax aggressiveness which is deemed incompatible with their position within the scope of sharia. And it is hoped that this research can contribute with new evidence about the tax aggressiveness that occurs in mining companies that have joined the Indonesian Sharia Stock Index (ISSI). In addition, the reason for choosing objects in ISSI companies is because Indonesia is the largest Muslim country so that it allows the distribution of the most Islamic shares, and also ISSI is still relatively new because it was launched on May 12, 2011 (Kayo, 2017).

Based on the description above, the authors need to conduct research related to the effect of debt policy, profitability and Corporate Social Responsibility (CSR) on tax aggressiveness in mining companies listed in the Indonesian Sharia Stock Index (ISSI) in the 2014-2019 period.

\section{Literature Review}

\section{Agency Theory}

Agency theory is a theory that explains the relationship between the business owner (principal) and the management (agent) (Natalya, 2018). Agency theory occurs because of an agreement between the two of them in running their company to achieve the main goals. In agency theory, information asymmetry can lead to a conflict of interest. The emergence of a conflict of interest between the agent and the principal is due to the difference in interests between the two (Inayaturrohmah \& Puspitosari, 2019). 
The influence of debt policies, profitability, and ...

\section{Debt Policy}

The debt policy is a policy from the company (management) by making decisions in obtaining funding sources from outside loans that are used for activities related to company operations, or it can be interpreted as the company's policy on how far the company uses debt financing (Inayaturrohmah \& Puspitosari, 2019). The explanation of debt is contained in the hadith narrated by Ibn Majah from Shuaib, Rasulullah SAW said:

"There are three things in which there are blessings, namely buying and selling with due payment, muqaradah, and mixing wheat for household needs, not for buying and selling".

The hadith explains three things in which there are blessings, one of which is muqarada (qardh) or debt. Debt obtained with the aim of providing benefit to the company will be a blessing for the company (Sapitri, 2018).

\section{Profitability}

Profitability is an ability that a company has in obtaining profits, which is done by using existing sources in the company (namely available capital, assets and sales). Or profitability can be interpreted as a performance indicator that explains the management of wealth which is usually carried out by company management with the aim of getting a profit from sales or investment (Maulana, 2019).

A verse of the Koran also explains about profitability as stated in Surah Ash-Shura verse 20, which reads:

"Whoever wants profit in the hereafter we will add to that profit for him and whoever wants profit in the world we give him a part of the profit in the world and there is no part for him in the hereafter". (Son, 2012)

The explanation of the verse is that Islam recommends mankind to develop their assets or capital used for business, by properly managing and controlling their assets. The main objective of establishing a business is to obtain maximum profit. Regardless of how much profit is obtained, as long as there are no elements of prohibition and injustice, it is permissible in Islam. 
Afiyatul Khafifah

\section{Corporate Social Responsibility}

Corporate Social Responsibility (CSR) is an act of social concern carried out by a company as a form of responsibility towards the community and also JIAFR | 118 the government with the existence of its business which it is feared could disrupt the surrounding environment and social activities in the community (Tarigan, 2016). In obtaining profits, the company must also pay attention to and apply the principles contained in Corporate Social Responsibility (CSR) for the successful implementation of the CSR program, including 1) Sustainability, which is related to the activities carried out by the company by considering the continuity and existence of resources in the future, 2) Accountability, which is an effort made by a company to be open to the public, and to be responsible for all its activities, and 3) Transparency, which is one of the most important principles, especially for external companies (Ramila et al., 2016).

The importance of the principles contained in CSR activities is also explained in the QS. Al-A'raf verse 85, which reads:

"Then make perfect the measure and the weigh, and do not deduct for man the measures and the scales thereof, and do not cause damage to the face of the earth after God has repaired it". (Son, 2012)

The explanation of the verse is that we are required to give rights to others according to what has become their rights. And do not reduce the quantity or the scale that will be given. And do not destroy what is on the face of the earth, including the environment, because it is all God's creation.

\section{Tax Aggressiveness}

Tax aggressiveness is usually referred to as an action taken by management with the aim of minimizing the taxable profit of the company obtained through tax planning, whether legally or illegally (Megarani et al., 2019). Tax-aggressive companies are characterized by less transparency. Tax aggressiveness is also a tax planning activity carried out by companies by reducing the effective tax rate (Surya \& Noerlaela, 2018). 
An explanation of tax aggressiveness is provided in the QS. An-Nahl verse 105, which reads:

"Surely those who make up lies are only people who do not believe in the signs of Allah, and they are liars or liars". (Son, 2012)

The explanation of the above verse is a person who lies in all respects is a person who does not believe in Allah and is hated by Allah. Doing tax aggressiveness is the same as a company lying by doing everything it can for the benefit of its business without thinking about the cause and effect in the future and not feeling afraid at all. A company can be considered as not caring about social conditions if it carries out tax aggressiveness (Wahyu, 2015).

Tax aggressiveness is measured using the effective tax rate (ETR) method, which is measured by dividing income tax expense with profit before tax. ETR is used to find out how much tax rates that must be borne by the company, as a proxy for calculating tax aggressiveness because ETR is able to provide a comprehensive picture of changes in tax burden. The small amount of income tax expense compared to profit before tax results in a low ETR value, thus causing an increase in tax aggressiveness (Prasista \& Setiawan, 2016).

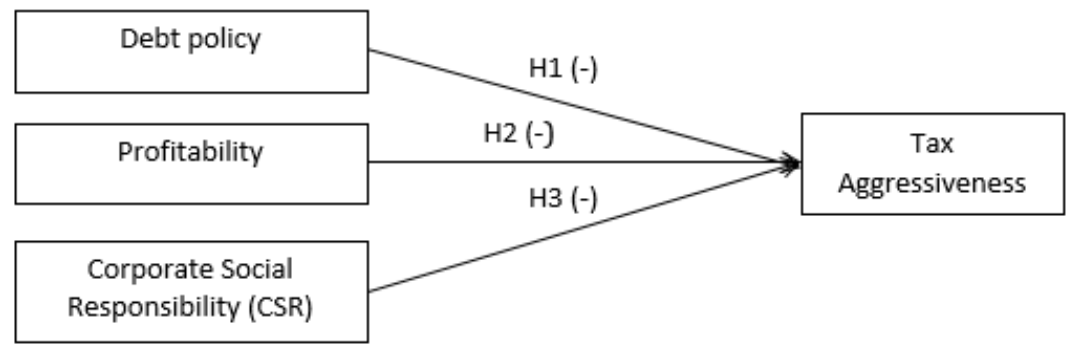

Figure 1. Research Framework 


\section{Hypothesis Development}

\section{The Effect of Debt Policy on Tax Aggressiveness}

JIAFR | 120

Debt policy can also be interpreted as a company's policy on how far the company uses debt financing (Sapitri, 2018). Nugraha and Meiranto (2016) explain that debt policy has a negative effect on tax aggressiveness. In agency theory, it occurs when the decision of the agent to carry out a debt policy is approved by the principal (the owner of the company), because the principal fully supports the agent's actions for the good and progress of his company. For companies with high debt policies, the more parties will supervise, so that the agent (company management) will find it difficult to take aggressive tax actions, the agent will report and pay taxes according to the company's circumstances. So the tax collector as the principal benefits (A'yun, 2019).

$H_{1}$ : $\quad$ Debt Policy has a negative significant effect on tax aggressiveness

\section{Effect of Profitability on Tax Aggressiveness}

Profitability is the ability of an organization in the future to get benefits (Tarigan, 2016). With high profitability, it also leads to higher profitability. Therefore, in agency theory, it requires the agent to manage the company as good as possible so that it can fulfill its obligations to pay taxes, and at the same time it does not reduce the success of the agent's performance (A'yun, 2019).

Study by Kandaka and Pratiwi (2018) shows that profitability has a negative and significant effect on tax aggressiveness. High profitability means that the company will be able to easily pay the taxes charged, so that the principal (tax collector) feels benefited by the high profitability (Pratiwi, 2017).

$\mathrm{H}_{2}$ : Profitability has a significant negative effect on tax aggressiveness. 


\section{The Influence of Corporate Social Responsibility (CSR) on Tax Aggressiveness}

CSR is an action taken by a company as a form of concern for its social environment and the existence of a social contact relationship between the company and the community and environmental social disclosure (Jessica \& Toly, 2014). Tax aggressiveness also reflects an attitude of irresponsibility because it can only increase company profits, but on the other hand, these actions can harm the state because it causes a decrease in state income from taxes (Prasista \& Setiawan, 2016).

Fionasari et al. (2017) revealed that CSR has a significant negative effect on tax aggressiveness. In agency theory, the agent (company management) will take CSR actions, where companies that carry out CSR reflect companies that have high social responsibility, so that the company will not take tax aggressiveness that is detrimental to the principal (tax collector).

$H_{3}$ : Corporate Social Responsibility (CSR) has a negative effect on tax aggressiveness.

\section{Research Methods}

This type of research is quantitative research. The type of data is secondary data obtained through the company website www.idx.co.id. The population in this study are mining companies listed in the Indonesian Sharia Stock Index (ISSI) in the 2014-2019 period, with a total of 33 companies. The sample selection in this study used purposive sampling technique, namely techniques to determine samples based on certain considerations. The criteria that are taken into consideration in determining the sample include: 1) Mining sector companies listed in the Indonesian Sharia Stock Index (ISSI) for the 2014-2019 period. 2) The company did not experience delisting. 3) Companies that publish annual reports. 4) Companies with ownership of the data required in the study.

Based on the sample criteria above, the research sample is 6 companies. Researchers use ready-made documents (company annual financial 
Afiyatul Khafifah

statements). Annual financial reports are obtained from the company website.

Independent variable included: 1) To measure debt policy using the Debt to Asset Ratio (DAR). This ratio can measure the size of the company's debt when compared to the company's own capital. The higher the DAR ratio, the bigger the company's debt and the large taxes paid (Hartadinata \& Tjaraka, 2013). 2) The ROA (Return on Asset) ratio is used in this study to measure the company's profitability. ROA is a ratio measured by comparing net income before tax with total total assets at the end of the period. High ROA shows that the profit the company gets is also higher and the taxes paid are also large (Rinaldi \& Cheisviyanny, 2015). 3) The measurement of CSR in this study was measured by GRI-G4 which contained a total of 91 items. If a company discloses an item then it is given a value of 1 and if not then it is assessed as 0 . The grading is then added up and the total CSR items are obtained. Furthermore, the total items disclosed in each dimension are compared with the maximum total items disclosed (Jessica \& Toly, 2014).

Dependent variable included the dependent variable of this study is tax aggressiveness. To measure tax aggressiveness, the Effective Tax Rate (ETR) model is used. ETR shows the percentage of the total amount of income tax expense that is borne by the company from the total amount of income before tax. A low ETR indicates that tax aggressiveness is low. The size of the ETR value is determined by a percentage of $25 \%$. If the ETR value is lower than $25 \%$, it indicates aggressive tax action, and vice versa, if the ETR is higher than $25 \%$, the tax aggressiveness is low. The cause of low ETR is because the income before tax is greater than the income tax burden (Rinaldi \& Cheisviyanny, 2015). In this study, the analysis technique used is multiple regression in hypothesis testing. 
The influence of debt policies, profitability, and ...

\section{Results and Discussion}

\section{Description of The Research Object}

The objects in this study are mining companies listed in the Indonesian Sharia Stock Index (ISSI) during the 2014-2019 period. There were 6 mining companies listed in the ISSI that match the criteria in this study during the 2014-2019 period, displayed on table 2 .

\section{Multiple linear regression}

This test is to determine the effect of debt policy efficiency, profitability, and CSR on tax aggressiveness. Based on the multiple linear regression equation, it can be interpreted as follows: 1) The value of the constant $(\alpha)$ is -0.133 , which states that if the independent variable is equal to 0 , the constant value can reduce the value of ETR (tax aggressiveness measure) by 0.133 . 2) The value of the $\mathrm{X} 1$ coefficient is positive at 0.387 , if every 1 value is added to the debt policy variable, it is followed by an increase in the ETR (tax aggressiveness gauge) value of 0.387 . 3) The value of the X2 coefficient is positive, namely 0.171 , if each additional 1 value is added to the profitability variable, it is followed by an increase in the value of the ETR (tax aggressiveness gauge) of 0.171. 4) The value of the X3 coefficient (CSR) is positive, namely 0.656 , which indicates that if every 1 value is added to the CSR variable, it will be followed by an increase in the value of the ETR (tax aggressiveness gauge) of 0.656 .

Table 2. List of Mining Companies Registered in the Indonesian Sharia Stock Index (ISSI) for the period 2014-2019

\begin{tabular}{ccl}
\hline No. & Company Code & \multicolumn{1}{c}{ Company name } \\
\hline 1 & PTBA & PT. Bukit Asam Tbk \\
2 & ITMG & PT. Indo Tambangraya Megah Tbk \\
3 & ELSA & PT. Elnusa Tbk \\
4 & ADRO & PT. Adaro Energy Tbk \\
5 & TOBA & PT. Toba Bara Sejahtera Tbk \\
6 & DSSA & PT. Dian Swastika Tbk \\
\hline
\end{tabular}

Source: idx.co.id

Journal of Islamic Accounting and Finance Research - Vol. 3 No. 1 (2021) 
Afiyatul Khafifah

Table 3. Multiple Linear Regression Test Results

\section{Coefficients}

JIAFR | 124

\begin{tabular}{llccccc}
\hline Model & \multicolumn{2}{c}{$\begin{array}{c}\text { Unstandardized } \\
\text { Coefficients } \\
\text { Std. Error }\end{array}$} & $\begin{array}{c}\text { Standardized } \\
\text { Coefficients } \\
\text { Beta }\end{array}$ & T & Sig. \\
\hline 1 & (Constant) &,- 133 &, 095 & & $-1,399$ &, 171 \\
& X1 &, 387 &, 185 &, 308 & 2,090 &, 045 \\
& X2 &, 171 &, 230 &, 099 & 1,757 &, 049 \\
& X3 &, 656 &, 172 &, 542 & 3,808 &, 001 \\
\hline
\end{tabular}

a. Dependent Variable: $Y$

\section{Determinant Coefficient Test}

This test is to find out how much the ability of the model to express the dependent variable. The $\mathrm{R}$ square value is 0.511 , indicating that the ability of the independent variable to explain the dependent variable is $51.1 \%$. While the remaining $50.1 \%$ is explained by other variables not included in this study.

\section{Simultaneous Significance Test}

This test is to find out whether if all the dependent variables are included in the model simultaneously it can affect the independent variables. The results of the $\mathrm{F}$ table is 2.87 and the $\mathrm{F}$ count is 11.160 with the results of $\mathrm{F}$ count (11.160)> F table (2.87), while the significant value shows the value of 0.000 where the value is less than 0.05 (sig. $0.000<0.05$ ) (significant). So, it can be concluded that all independent variables simultaneously have a significant influence on the dependent variable.

Table 4. The results of The Determinant Coefficient Test

\section{Model Summary}

\begin{tabular}{rrrrr}
\hline Model & $\mathrm{R}$ & R Square & $\begin{array}{c}\text { Adjusted R } \\
\text { Square }\end{array}$ & $\begin{array}{c}\text { Std. Error of the } \\
\text { Estimate }\end{array}$ \\
\hline 1 &, $715 a$ &, 511 &, 465 &, 090 \\
\hline
\end{tabular}

a. Predictors: (Constant), X3, X2, X1

b. Dependent Variable: $Y$ 
The influence of debt policies, profitability, and ...

Table 5. Simultaneous Significant Test Results

ANOVAb

\begin{tabular}{llrrrrr}
\hline & Model & Sum of Squares & Df & Mean Square & $F$ & Sig. \\
\hline 1 & Regression &, 272 & 3 &, 091 & 11,160 &, $000 a$ \\
& Residual &, 260 & 32 &, 008 & & \\
& Total &, 531 & 35 & & & \\
\hline
\end{tabular}

JIAFR | 125

a. Predictors: (Constant), X3, X2, X1

b. Dependent Variable: $Y$

Partial Regression Test (T test)

Table 6. Partial Regression Test Results (T Test)

Coefficients

\begin{tabular}{lcrrrrr}
\hline \multirow{2}{*}{ Model } & \multicolumn{2}{c}{$\begin{array}{c}\text { Unstandardized } \\
\text { Coefficients }\end{array}$} & $\begin{array}{c}\text { Standardized } \\
\text { Coefficients } \\
\text { Beta }\end{array}$ & $\mathrm{t}$ & Sig. \\
\hline 1 & B & Std. Error & Beta & & \\
\hline & &,- 133 &, 095 & & $-1,399$ &, 171 \\
& X1 &, 387 &, 185 &, 308 & 2,090 &, 045 \\
& X2 &, 171 &, 230 &, 099 & 1,757 &, 049 \\
& X3 &, 656 &, 172 &, 542 & 3,808 &, 001 \\
\hline
\end{tabular}

a. Dependent Variable: $Y$

This test is to detect whether partially there is an influence between the dependent variable on the independent variable. The results of processing the partial regression test data, in order to obtain the following conclusions: 1) In the debt policy (X1), the value of Tcount is 2.090 and a significant value is 0.045 , while $\mathrm{T}$ table is 1.692 . Value (tcount) $2,090>$ (ttable) 1,692 with a significant value of $0.045<\alpha 0.05$, then $t$ is concluded that the debt policy variable (X1) has a significant effect on tax aggressiveness (Y). 2) In the profitability variable (X2), the T-count value is 1.757 and the significant value is 0.463 and the T-table is 1.692 . This means that the value (tcount) is $1.757>$ (ttable) 1.692 and a significant value is $0.049<\alpha 0.05$, and it is concluded that the profitability variable (X2) has a significant effect on tax aggressiveness (Y). 3) The CSR variable shows that the value of t count is 3.808 while the value of 
Afiyatul Khafifah

t table is 1.692 . While the acquisition of a significant value is 0.001 , indicating the value (tcount) 3.808> ( $\mathrm{t}$ table) is 1.692 and a significant value is 0.001 $<0.05$. So, it is concluded that the CSR variable (X2) has a significant effect on

JIAFR | 126 tax aggressiveness $(\mathrm{Y})$.

\section{Debt Policy Affects Tax Aggressiveness (Hypothesis 1)}

The value of T-count in the debt policy variable is 2.090, the T-table is 1.692 , while the significant value is 0.045 which is smaller than 0.050 .045 $<0.05$ ) and has a positive coefficient of 0.387 . Based on this statement, it is concluded that the debt policy variable has a positive effect on the Effective Tax Rate (ETR) and has a negative effect on tax aggressiveness. That is, if the value of the debt policy increases, the ETR of the company will be higher or the taxes paid by the company will be higher so that the tax aggressiveness is low.

The negative influence that occurs is due to agency theory, where the existence of a debt policy chosen by the agent (company management) makes many parties such as stakeholders, government, OJK and others oversee every company activity including in making financial reports, so that the agent cannot move. Tax report is done according to the actual circumstances or conditions of the company so that even though the debt policy is high, the tax paid will be high. As a result, the principal (tax collector) will feel benefited by the amount of tax paid by the agent (company management).

The results of this study are consistent with previous research conducted by Hartadinata and Tjaraka (2016) regarding the effect of managerial ownership, debt policy and company size on tax agressiveness in manufacturing companies on the IDX (2008-2013), which states that debt policy has a negative effect to tax aggressiveness.

\section{Profitability Affects Tax Aggressiveness (Hypothesis 2)}

The value of T-count of the profitability variable is 1.757 , while the value of T-table is 1.692 . The acquisition of a significant value is 0.049 , where the value is less than $0.05(0.49<0.05)$ and has a coefficient value in a positive 
direction, that is 0.171 . This statement proves that the profitability variable has a positive effect on ETR (a measure of tax aggressiveness) and has a negative effect on tax aggressiveness. This shows that the greater the profitability obtained by the company, the higher the company's ETR or the higher the taxes paid by the company and the low tax aggressiveness because ETR has the opposite nature of tax aggressiveness.

Profitability has a negative effect on tax aggressiveness. In agency theory, there is a harmony or linkage between the agent and the principal where the success of the agent makes the company that has a large profitability so that the profit generated will increase. Therefore, the agent will not experience difficulties in fulfilling its obligations, one of which is the obligation to the government (principal) in paying taxes.

The results of this study are in accordance with previous research conducted by Robet (2017) entitled "The Effect of Corporate Social Responsibility and Profitability on Tax Aggressiveness in Manufacturing Companies Listed on the IDX", which states that profitability has a significant negative effect on tax aggressiveness.

\section{Corporate Social Responsibility (CSR) Affects Tax Aggressiveness (Hypothesis 3)}

The value of $t$ count is 3.808 , while the value of $t$ table is 1.692 . The result of the significant value is 0.001 , where the significant value is less than 0.05 $(0.001<0.05)$, and the coefficient value shows a positive direction, that is 0.656. Based on this statement, the results show that the Corporate Social Responsibility (CSR) variable has a positive effect on ETR (tax gauge) and has a negative effect on tax aggressiveness. This shows that the greater the company discloses its Corporate Social Responsibility (CSR), the higher the taxes paid by the company or the higher the ETR of the company. It indicates that the company's tax aggressiveness is low. So, it can be concluded that CSR has a negative effect on tax aggressiveness.

In agency theory, CSR has a negative effect on tax aggressiveness because the agent (company management) discloses high CSR. It shows that the company has a high sense of social responsibility, so that the company will 
Afiyatul Khafifah

also pay high taxes for the prosperity of society and also the country. As a result, the high tax payments can benefit the principal (tax collector/government).

JIAFR | 128

This study is in accordance with previous research by Gunawan (2017) which examines the effect of Corporate Social Responsibility and Corporate Governance on tax aggressiveness, and states that Corporate Social Responsibility has a negative effect on tax aggressiveness.

\section{Conclusion}

The results of the study indicate that (1) the debt policy variable (X1) has a significant negative effect on tax aggressiveness (Y), (2) the profitability variable (X2) has a significant negative effect on tax aggressiveness (Y), (3) the variable Corporate Social Responsibility (CSR) (X3) has a significant negative effect on tax aggressiveness (Y).

The three independent variables have a significant negative effect on tax aggressiveness. Therefore, mining companies listed in ISSI, when viewed from their debt policy, profitability and Corporate Social Responsibility (CSR), indicate that the company is compliant with tax payments. However, in the future, the company should still maintain and improve the quality of the company, especially in paying taxes, so that it remains in accordance with its position within the scope of sharia.

\section{References}

Atari, J. (2016). The Effect of Managerial Ownership, Institutional Ownership, and Debt Policy on Aggressive Tax. JOM Fekon, 3(1), 113-1149.

Cahyani, R. (2016). The Effect of Profit Management and Corporate Social Responsibility on Tax Aggressiveness (Thesis). UIN Syarif Hidayatullah.

Darussalam. (2020). Is the 2020 Tax Target Realistic? DDTCNews. https://news.ddtc.co.id/realistiskah-target-pajak-202018856?page $y=0$.

Fionasari, D., Savitri, E., \& Andreas, A. (2017). The Effect of Corporate Social Responsibility Disclosure on Tax Aggressiveness. Highlight, 12(2), 95. https://doi.org/10.31258/sorot.12.2.4557. 
Gabrillin, A. (2018). KPK Calls Out of 11,000 Mining Permits, Nearly 4,000 Problematic Licenses. Compass. www.Kompas.com.

Gunawan, J. (2017). The Influence of Corporate Social Responsibility and Corporate Governance on Tax Aggressiveness. Journal of Accounting, 21(3), 425. https://doi.org/10.24912/ja.v21i3.246.

Hartadinata, O. S., \& Tjaraka, H. (2013). Analysis of the Influence of Managerial Ownership, Debt Policy, and Company Size on Tax Aggressiveness. Journal of Economics and Business, 23(3), 48-59.

Hengky, R. M. T. (2016). The Influence of Corporate Social Responsibility and Profitability on Tax Aggressiveness. 2004, 12-20.

Inayaturrohmah, A., \& Puspitosari, I. (2019). The Effect of Maqashid Syariah Index, Profitability and Corporate Social Responsibility on Tax Aggressiveness. At-Tijaroh: Journal of Management Science and Islamic Business, 5(1), 98-115. https://doi.org/10.24952/TIJAROH.V5I1.1691.

Jessica, \& Toly, A. A. (2014). The Effect of Corporate Social Responsibility Program Disclosure. Tax \& Accounting Review, 4(1), 193-203.

Kayo, E. sutan. (2017). Sharia Shares (ISSI) on the IDX. Sharia Shares. https://www.sahamok.com/saham-syariah/

Latifah, N. U. (2018). The Influence of Corporate Governance, Capital Intensity and Inventory Intensity on Tax Aggressiveness. IAIN Surakarta, 1, 43. https://doi.org/10.1017/CB09781107415324.004.

Maulana, H. (2019). Effect of ROA, Leverage and Company Size on Tax Avoidance (Thesis S1). UIN Walisongo Semarang.

Megarani, N., Warno, W., \& Fauzi, M. (2019). The effect of tax planning, company value, and leverage on income smoothing practices in companies listed on the Jakarta Islamic Index. Journal of Islamic Accounting and Finance Research, 1(1), 139. https://doi.org/10.21580/jiafr.2019.1.1.3733.

Natalya, D. (2018). The Influence of Capital Intensity, Leverage and Profitability on Tax Aggressiveness with Market Performance as a Moderating Variable. Media Tax Accounting, 3(1), 37-55.

Prasista, P., \& Setiawan, E. (2016). The Effect of Profitability and Disclosure of Corporate Social Responsibility on Income Tax Aggressiveness of Corporate Taxpayers. E-Journal of Accounting, 17(3), 2120-2144. 
Afiyatul Khafifah

Pratiwi, K. R. (2017). The Influence of the Audit Committee, Leverage, and Profitability on Tax Aggressiveness (Studies in the Consumer Goods Industry Sector Companies Listed on the Indonesia Stock Exchange for the Period 2012-2015). Department of Accounting STIE, 3(4), 56-73.

JIAFR | 130 Putra, A. T. (2012). Al-Quran and its Translation (Arabic-Latin Transliteration) Right-Left Model. CV. Ash-Syifa.

Qurrota, A. (2019). The Influence of Corporate Social Responsibility, Corporate Governance and Profitability on Tax Aggressiveness. UMM.

Rakhma, E. (2018). The Effect of Corporate Social Responsibility Disclosure on Tax Aggressiveness. Journal of Accounting and Information Systems, 3(2), 82-92.

Ramila, Rambe, P. A., \& Ruwanti, S. (2016). The Influence of Corporate Social Responsibility, Profitability, Leverage and Capital Intensity on Tax Aggressiveness in Manufacturing Companies Listed on the Indonesia Stock Exchange in 2013 - 2016. Journal of Economics UMRAH, 15(2), 115.

Renny, S., \& Joko, S. H. F. (2019). The effect of company size and leverage on tax avoidance empirical case study on chemical sub-sector companies on the Indonesian stock exchange for the period 2013-2017. Accounting, 1-15.

Rinaldi \& Cheisviyanny, C. (2015). The Effect of Profitability, Company Size and Fiscal Loss Compensation Against Tax Avoidance (Empirical Study of Manufacturing Companies Listed on the IDX 2010-2013). National Seminar on Management and Accounting Economics (Snema), Faculty of Economics, Padang State University, c, 472-483. http://fe.unp.ac.id/

Sapitri, E. (2018). Effect of Liquidity and Profitability on Debt Policy. Raden Intan University.

Surya, S., \& Noerlaela, S. (2018). The Effect of Profitability and Leverage on Tax Aggressiveness. Journal of Management Science \& Accounting, 7(1), 101-118.

Wahyu, B. N. (2015). The Influence of Corporate Social Responsibility, Company Size, Profitability, Leverage and Capital Intensity on Tax Aggressiveness. Journal of Accounting, 4(4), 1-15. 